\title{
Echocardiography-guided tricuspid valve replacement by extracted extracellular matrix in post-traumatic tricuspid regurgitation
}

\author{
Paweł Czub $^{1} \cdot$ Monika Budnik $^{1}$ (D) $\cdot$ Adam Arendarczyk ${ }^{1} \cdot$ Janusz Kochanowski $^{1}$
}

Received: 1 August 2020 / Accepted: 6 August 2020 / Published online: 14 August 2020

(c) The Author(s) 2020

Extracted extracellular matrix (Cor Matrix) applies growth factors, matricellular proteins, glycosaminoglycans and adhesion factors. After implantation into human tissue, CorMatrix functions as a scaffold onto which the body's own cells migrate. The matrix itself dissolves after 6-8 months, leaving new leaflets built of patient fibroblasts. Until now it was used mainly as a patch in intracardiac shunts and in patients with endocarditis.

A 49-year old patient with severe tricuspid regurgitation secondary to prolapse of the anterior leaflet as a result of the rupture of the chordae tendineae following non-penetrating chest trauma with features of progressive symptomatic right ventricular (RV) dysfunction was admitted to the Department of Cardiac Surgery. In echocardiography significant $\mathrm{RV}$ and right atrium dilatation was diagnosed (RVIT AP4C basal $7.5 \mathrm{~cm}$, RAA $46 \mathrm{~cm}^{2}$, RAV $236 \mathrm{ml}$ ) as well as tricuspid annulus dilatation to $58 \mathrm{~mm}$ (Fig. 1a-c). The tricuspid valve was reconstructed using CorMatrix material. The valve was sewn before chest opening to fit with the size of the ring and the distance of the leaflets to the papillary muscles. The loci of attachment for papillary muscles have now been reconstructed. Intraoperatively, good coaptation of the leaflets with only mild regurgitation was observed (Fig. 1d). Postoperative ECHO revealed normal valvular function, with mild regurgitation without increase of transvalvular gradient. The results of controlling echocardiography performed with intervals of 6 months, a year, two and three years, revealed a good treatment effect and proper valve function. Moreover, RV dimension has significantly decreased (Fig. 1e, f).
Monika Budnik

moni.budnik@gmail.com

1 Medical University of Warsaw, Warsaw, Poland 


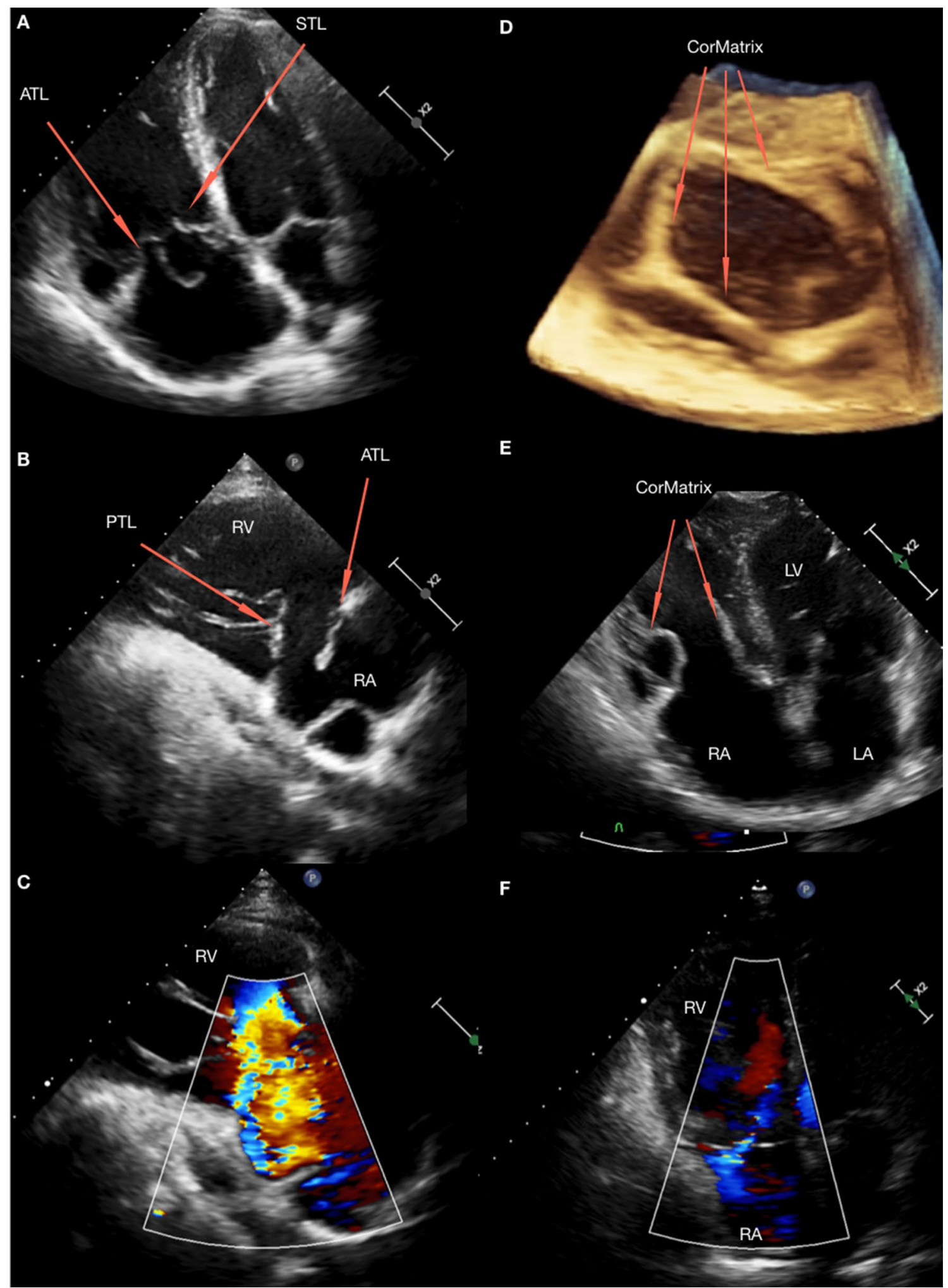

Fig. 1 a, b Transthoracic echocardiography at admission- tricuspid valve leaflets, prolapse of the anterior leaflet, RV enlargement. c Transthoracic echocardiography at admission- severe tricuspid regurgitation. d 3D Intraoperative transesophageal echocardiographytricuspid reconstruction using CorMatrix. e Follow-up transthoracic echocardiography—reduction of RV enlargement, proper valve function. f Follow-up transthoracic echocardiography-mild tricuspid regurgitation. $A T L$ anterior tricuspid leaflet, $L A$ left atrium, $L V$ left ventricle, $P T L$ posterior tricuspid leaflet, $R A$ right atrium, $R V$ right ventricle, STL septal tricuspid leaflet 
Author contributions All authors edited and approved the final version of the manuscript.

\section{Compliance with ethical standards}

Conflict of interest The authors declared that they have no conflict of interest.

Open Access This article is licensed under a Creative Commons Attribution 4.0 International License, which permits use, sharing, adaptation, distribution and reproduction in any medium or format, as long as you give appropriate credit to the original author(s) and the source, provide a link to the Creative Commons licence, and indicate if changes were made. The images or other third party material in this article are included in the article's Creative Commons licence, unless indicated otherwise in a credit line to the material. If material is not included in the article's Creative Commons licence and your intended use is not permitted by statutory regulation or exceeds the permitted use, you will need to obtain permission directly from the copyright holder. To view a copy of this licence, visit http://creativecommons.org/licenses/by/4.0/.

Publisher's Note Springer Nature remains neutral with regard to jurisdictional claims in published maps and institutional affiliations. 